\title{
Notes from the Field: \\ Contemporary Folkways in Slovenia: Personal Practices of Commemoration at Cemeteries, Public Monuments, and Unmarked Mass Graves
}

\author{
Veronica E. Aplenc \\ Rosemont College \\ Rosemont, Pennsylvania, USA
}

While monuments and practices of public commemoration have garnered quite a bit of attention in the North American academic literature in the past few years, cemeteries and practices of personal commemoration have remained less well explored. A lack of attention to these two very common and widespread folklore items can be found outside North America also. Highly present in the folkways of both village and urban people, and displaying similarity across political divides, these two topics have oddly remained absent in the Slovenian academic literature. These field notes present the initial stages of a research project into personal practices of commemoration that proliferate at Slovenian cemeteries as well as monuments. Building on initial fieldwork conducted in 2001 and 2002, my research points to commonalities in the form of cemeteries, similarities which derive from a shared history. There are also similarities in practices of personal commemoration across significant geographical, social, and political divides. While the first observation is not surprising, the second one points to the striking continued presence of these folkways through the socialist and post-socialist periods across major societal divisions.

Cemeteries are very widespread in Slovenian villages and towns and the everyday practices associated with them are a fascinating topic of research. Largely rectilinear, Slovenian cemeteries recall the more formal layouts found in French examples, rather than the naturalistic style of Anglo-American or Protestant northern European places of burial. Generally entered through gates and surrounded by walls, Slovenian cemeteries adjoin churches or are free-standing, with village examples often falling in the first category and city ones in the second. Similar to their Italian counterparts, Slovenian cemeteries are divided in grid-like fashion into neat rows of plots. Rows of gravel or, in the case of village cemeteries, neat dirt paths, mark the grid lines. Plots, in turn, generally contain a single family gravestone with several individuals' names, rather than markers to individuals. Gravestones are placed at the head of 
grave plots and those of the twentieth century usually take the form of a rectangular stone slab of limestone, granite or marble. A progression of styles can be noted across the nineteenth and twentieth centuries in gravestone overall shape, lettering style, modest decoration, and in materials. The entire plot is often treated like a small garden and can include an ivy covering, individual plants in a gravel bed, or a combination of gravel, stone slabs and plantings. Care for family plots occupies a very important place in both urban and village folkways, with expectations that a well-cared for plot will be tidy, contain managed plantings, and remain weed-free. Both gravestones and plots often assume a quiet appearance, with little that can be characterized as ostentatious or flamboyant.

Slovenian cemeteries share their form with counterparts in the broader Western European, historically Roman Catholic, region of which Slovenia has been a part since the early medieval period. Because Slovenian territory fell predominantly under Austrian, but also Italian, French, and Hungarian rule until 1918, the political, religious and social forces of these states greatly shaped Slovenian life. As argued by Mateja Habinc, by the time of the Enlightenment, Slovenian burial grounds were appearing as square courtyards adjoining churches. From the late eighteenth century onward, cemeteries increasingly came under governmental management in a reflection of changing church-state relations, secularization, and emerging ideas on public hygiene. In the nineteenth-century Habsburg Empire, cemeteries fell under either state or Roman Catholic Church administration, depending on their location, and the state issued legislation on the specifics of cemetery location and construction. The form of contemporary Slovenian cemeteries including surrounding walls and, for new cemeteries, locations outside settlements - is a direct consequence of the requirements of eighteenthand nineteenth-century Austrian legislation. Following the Second World War and the introduction of the Yugoslav socialist state, cemeteries were fully secularized and, at the time of this writing, burials in Slovenia are regulated by a 1984 law (Habinc 21-30). The Ljubljana city cemetery, for example, is currently owned by a state funerary company (Žale javno podjetje, d.o.o.) which manages all burials within the cemetery, as well as all cemetery matters. In an unusual arrangement that stands out against otherwise highly ordered management practices, the Ljubljana city cemetery company requires individuals who own family graves to also pay a fee, termed "annual rent," on these plots. 
Practices of personal commemoration in Slovenia derive from those historically present in the greater region, although the specifics of these folkways are particular to the country. The main holiday for personal commemorations of the deceased has remained the same since 1918 and three states - monarchical Yugoslav, socialist Yugoslavia, and independent Slovenia - have maintained it under different names. The first of November was known by the religious term Vsi sveti (All Saints') before the Second World War. Interestingly it became Dan mrtvih (The Day of the Dead) during the socialist period. It has been called Dan spomina na mrtve (literally, Day of the Remembering of the Dead) in the independence period, that is since 1991. Individuals commemorate the deceased on other holidays, too, such as Christmas or/and New Year's. Such commemorations are based on individuals' beliefs and the anniversary of date of death. Commemorative practices most commonly include the placing of candles on loved ones' graves, while the laying of flowers and floral arrangements occurs less frequently.

These practices flourish among all Slovenians, despite significant geographical, social and political divisions. Habinc dates the origins of candle-placing to early Christian religious rituals, and the historical association of this practice with Catholicism is clear. Its migration over time to a folk practice common to Catholic believers, the religiously nonaffiliated, and active (anti-religious) Communists today strikes one as plausible, and field observations support its apparently universal nature. For example, during field visits to the Ljubljana city cemetery in 2001 and 2002 on November 1, I noticed numerous candles lit at all cemetery sites marking the deceased. Multiple candles were placed at family plots. These were for individuals. Candles stood several rows deep around the very small, semi-circular garden behind the cemetery Church of the Holy Cross. These were for those with no identified grave, meaning those killed by communist forces during the Second World War and immediately thereafter. There were also seas of candles under various monuments to war-time partisans. These were for pro-communist fighters who died during the Second World War.

While personal commemorative practices at cemeteries have received limited discussion in the Slovenian literature, no examination can be complete without a consideration of personal commemoration at monuments to the Second World War and related events. As part of the former Yugoslavia, Slovenia experienced occupation by fascist forces during World War II, as well as intense internal fighting that verged on civil war. The political divides of the war-time period can be roughly 
grouped into pro-communist, or "red," and alternatively anti-communist, pro-fascist, and perhaps pro-Catholic, or "white," depending on the speakers' point of view. These divisions remain highly visible in Slovenian politics today. Evidence of this sharp political divide can be found in the disparate portrayals of politics in the main daily newspaper Delo (Labor), the weekly Mag (Mag), and the monthlies Ampak (However) and Mladina (Youth), as well as in commentary - from both sides - in political programs on the national television station Slovenija 1 (Slovenia 1), such as Odmevi (Echoes) and Tednik (Weekly). In the socialist period, the state erected numerous monuments to partisan wartime activity, including representational monuments to specific individuals or historical events, representational monuments to a generalized hero figure, and non-representational monuments to partisan anti-fascist efforts, the partisan movement, collective anti-fascist efforts, and individual historical events. On a side note, because Yugoslavia did not follow the Soviet Union from 1947 on, concerns with socialist realism as a style are not relevant for the Yugoslav case. Such socialistera monuments are located throughout Slovenia and, unlike other Central and East European countries, have not been removed since the political watershed of independence in 1991. Rather, they continue to stand and to be the sites of practices of personal commemoration - a reflection, I argue, of the continuing significance and acceptance of socialist political identity in the contemporary Slovenian sense of self. For example, in 2001 and 2002, November 1 was marked by a sea of candles beneath several towering monuments erected to partisan fighters. These monuments stand at the edge of the Ljubljana city cemetery and on a path called "The Path of Comradeship and Remembrance." This twentyplus-kilometer-long monument was planned in the late $1950 \mathrm{~s}$ as a commemorative-recreational site marking the barbed wire ring with which Italian fascist forces closed off the city during war-time occupation. In the early 2000 s, the path remained heavily used for the purposes - commemoration and recreation - for which it was designed.

In parallel with practices at these state-created monuments to "the fallen," or partisan war-time fighters, one must also mention a phenomenon on the opposite end of the political spectrum, that of personal commemoration at mass graves of war-time opponents to the communists. These are quite numerous in Slovenia and are estimated to number over 500. They range from small sites such as the deep cave, less than $1 \mathrm{~m}$ in diameter, that was shown to me by a friend in the rural Primorska region and is believed to be a mass grave - to very large ones 
containing the remains of up to 1,500 individuals. Remaining a very contested topic in the Slovenian political arena, public discussion of these sites has proven tense and difficult. These sites, too, are the recipients of personal commemoration practices. An easily accessible example for North Americans can be found in the 2008 Slovenian film Pokrajina št. 2 (Landscape No. 2), a political thriller whose trailer and closing scene feature a thief running through a sea of lights in a forest. Odd to a non-Slovenian and perhaps even suggestive to North Americans of folk practices related to pagans, to a Slovenian the candles and forest setting clearly point to only one phenomenon, that of personal commemoration at an unmarked war-time or post-war mass grave.

Although Slovenian cemeteries and graveside practices are of interest to folklorists, personal commemoration in the Slovenian context has relevance beyond a single discipline. Historians, art historians and, to some degree, architects have teased out the intricacies of cemeteries, their histories, and their relationship to broader intellectual trends. Similarly, folklorists and anthropologists have concerned themselves with rituals and practices at funerals across cultures, while scholars of diverse backgrounds have considered the politics of public commemorations. The Slovenian case has features that cross disciplinary boundaries and reveals striking details about contemporary Slovenian folklore, culture, and identity. With contemporary personal commemoration practices taking place at family gravesites, socialist-era public monuments to war-time heroes, and unmarked locations of mass graves of communists' opponents, these practices represent an intriguing folklore item. Uniting as they do a highly divided populace and occurring at a variety of sites, they suggest the relevance of history, and of personal relationship to history, for Slovenians. Furthermore, they clearly point to the continuing significance and acceptance of the socialist period for contemporary political identity. And, they additionally indicate the very strong presence and unselfconscious practice of historically established folkways in everyday urban and village life. The intriguing details of these practices of personal commemoration and the insights they provide into contemporary Slovenian life will be the questions that my future research will aim to explore.

\section{BIBLIOGRAPHY}

Brun, Neva, and Marjan Remic, (eds.), 1999. Tihi pomniki minljivega časa: Drobci o šegah slovesov in pokopališki kulturi na slovenskem

FOLKLORICA 2010, Vol. XV 
etničnem ozemlju. [Silent memorials of times past: Details on ceremonial customs and cemetery culture in the Slovenian ethnic territory.] Ljubljana: Forum 7.

Felicori, Mauro, and Annalisa Zanotti. 2004. Pokopaličša v Evropi: Zgodovinska dediščina, $k i$ jo je treba spoznati in ohraniti. [Cemeteries of Europe: Historic heritage that must be known and preserved.] Ljubljana: Mestna Občina Ljubljana.

Habinc, Mateja. 2000. "Gresta v nedeljo popoldne na pokopališče?" $O$ skrbi za grobove in njihovem obiskovanju na primeru brežiških pokopališč od tridesetih let 20. stoletja do danes. ["Are you going to the graveyard on Sunday afternoon?" On maintaining graves and visiting them; the example being the Brežice graveyards from the 1930s to the present day.] Ljubljana: Slovensko etnološko društvo, Ljubljana.

Slovenia: Mass Grave Found. New York Times. 5 March 2009.

http://www.nytimes.com/2009/03/05/world/europe/05briefs-

MASSGRAVEFOU BRF.html. Accessed 18 March 2010.

Slovenian Mass Grave Could Be Europe's Killing Fields. Der Spiegel. 21 August 2007.

http://www.spiegel.de/international/europe/0,1518,501058,00.html. Accessed 18 March 2010.

World War II mass graves open a wound in Slovenia. New York Times. 22 October 2007. http://www.nytimes.com/2007/10/22/news/22ihtslovenia.1.7995453.html. Accessed 18 March 2010. 